Educational Guidance and Counseling Development Jounal p-ISSN:2615-3661 | e-ISSN: 2615-8358

Vol. 1, No. 1, April2018, 52 - 69

\title{
MOTIVASI BELAJAR SISWA YANG BERLATAR BELAKANG BUDAYA MELAYU DAN JAWA
}

\author{
Hasgimianti ${ }^{1}$, Ramtia Darma Putri ${ }^{2}$, Raja Rahima MRA ${ }^{3}$ \\ ${ }^{1}$ Universitas Islam Negeri Sultan Syarif Kasim Riau \\ ${ }^{2}$ Universitas PGRI Palembang \\ ${ }^{3}$ Universitas Islam Negeri Sultan Syarif Kasim Rian \\ Email: hasgimi@gmail.com \\ tyadhuarma27@gmail.com \\ raja.rabima@yahoo.com
}

\begin{abstract}
Education is a process that students can use to develop their own potential.This was a descriptive comparative research which applied quantitative method. The essence of education is learning. There is no education without learning activities. Student learning motivation is influenced by the cultural background. By Slovin formulafollowed bysimple random sampling technique, 200 students were choosen as the sample at SMP Negeri 1 Siak Hulu Kabupaten Kampar in Academic Year 2015/2016. The data gathered were analyzed by using descriptive statistic and MANOVA (multivariate analysis of variance). The result of the research indicated that: The students' learning motivation with Malaynese cultural backgrounds are in the high category; The students' learning motivation with Javanese cultural backgrounds are are in very high category; and There is no significance different attention ofparentsbetween with MalayneseandJavanese cultural backgrounds, whilethere are siginificant differences in learning motivation. Learning motivationamongstudents whoMalaynesecultural backgrounds and Javanese cultural backgrounds. between thestudents'cultural backgrounds Malayneseand Javanese.
\end{abstract}

Keyword: Learning Motivation, Cultural Background

\section{PENDAHULUAN}

Pendidikan merupakan proses yang dapat dimanfaatkan siswa untuk mengembangkan potensi diri. Hal ini sesuai dengan tujuan pendidikan yang telah dirumuskan dalam Undang-undang Nomor 20 Tahun 2003 tentang Sistem Pendidikan Nasional Pasal 1 Butir 1 yang menjelaskan Pendidikan adalah usaha sadar dan terencana untuk mewujudkan suasana belajar dan proses pembelajaran agar peserta didik secara aktif mengembangkan potensi dirinya untuk memiliki kekuatan spiritual keagamaan, pengendalian diri, kepribadian, kecerdasan, akhlak mulia, dan keterampilan yang diperlukan dirinya, masyarakat, bangsa dan negara.

Inti dari pendidikan adalah belajar.Tidak ada pendidikan tanpa kegiatan belajar. Belajar adalah suatu proses yang dilakukan oleh seseorang untuk memperoleh ilmu pengetahuan dan suatu perubahan baik perubahan sikap atau tingkah laku. Proses belajar siswa dipengaruhi oleh lingkungan sekolah dan lingkungan keluarga. Orangtua mempunyai peranan dan tanggung jawab yang besar dalam keluarga.Menurut Silalahi \& Meinarno (2010), keluarga sering disebut sebagai institusi terkecil yang ada dalam masyarakat, mulai dari hubungan antar individu, otoritas, pola pengasuhan, pembentukan karakter, masuknya nilai-nilai masyarakat, dan lain-lainnya.Oleh karena 
itu, banyak ragam ilmu yang menelaah tentang keluarga, misalnya antropologi, sosiologi, psikologi, ekonomi, demografi, serta pendidikan.

Menrut Elliott, Kratochwill, Cook, \& Travers (1996:330) menjelaskan "Motivation arouses, sustains, directs and integrates behavior. When you are motivated, or when you observe that your students are motivated, you usually can discover the source of the motivation". Dari pendapat tersebut dapat dipahami bahwa motivasi dapat membangkitkan, menopang, mengarahkan, dan mengintegrasikan perilaku.Jika seseorang termotivasi, maka dapat menemukan sumber dari motivasi itu sendiri.

Motivasi seseorang didorong oleh adanya kebutuhan dalam dirinya.Maslow (dalam Majid, 2013) menjelaskan pada dasarnya manusia memiliki kebutuhan pokok.Tingkatan kebutuhan tersebut dikenal dengan sebutan hierarki kebutuhan Maslow.Manusia memulai dorongan dari tingkatan terbawah.Dengan adanya dorongan untuk memenuhi kebutuhan tersebut, seseorang hendaknya dapat menimbulkan motivasi bagi dirinya.

Pencapaian hasil belajar dipengaruhi oleh motivasi belajar dan dipengaruhi oleh latar belakang kebudayaan siswa tersebut. Ihromi (1999) menjelaskan bahwa kebudayaan pada umumnya mencakup cara individu berpikir, berperilaku serta cara individu bertingkah laku yang menjadi ciri khas suatu bangsa atau masyarakat dalam kebudayaan tertentu. Kebudayaan terdiri dari hal-hal seperti bahasa, ilmu pengetahuan, hukum-hukum, kepercayaan, agama, kegemaran makanan tertentu, musik, kebiasaan pekerjaan, larangan-larangan, dan sebagainya.

Kebudayaan merupakan keunikan suatu bangsa atau masyarakat. Ihromi (1999) menjelaskan bahwa kebudayaan pada umumnya mencakup cara individu berpikir, berperilaku serta cara individu bertingkah laku yang menjadi ciri khas suatu bangsa atau masyarakat dalam kebudayaan tertentu. Kebudayaan terdiri dari hal-hal seperti bahasa, ilmu pengetahuan, hukumhukum, kepercayaan, agama, kegemaran makanan tertentu, musik, kebiasaan pekerjaan, laranganlarangan, dan sebagainya.Dalam budaya ada sistem yang disebut dengan patriarki.Patriarki adalah sistem sosial yang menempatkan laki-laki sebagai sosok yang utama.Anak laki-laki pada sistem patriarki memiliki keunggulan dalam aspek tertentu dibandingkan dengan perempuan. Ayah memiliki otoritas terhadap perempuan, anak dan benda. Budaya yang menganut sistem patriarki biasanya berasal dari garis keturunan patrilineal.Budaya Melayu dan Jawa adalah budaya yang patriarki.

Secara harfiah, kata Melayu berasal dari kata "Mala" yang berarti mula dan "Yu" yang berarti negeri, selanjutnya dinisbahkan kepada kata "Ganggayu" yang berarti negeri Cingga.Dalam masyarakat Melayu sistem kekerabatan yaitu sistem kekerabatan patrilineal yang menarik garis keturunan dari ibu. Vallentijen (dalam Suwardi, 2007) menjelaskan orang Melayu tergolong cerdik, pintar, bersih cara hidupnya, dan pada umumnya begitu rupawan di seluruh Asia. Sejarah telah mencatat masyarakat Melayu Riau merupakan penduduk asli di wilayahnya.Kehidupan sehari-hari masyarakatnya tampak dominan dipengaruhi kebudayaan Melayu.Walaupun dikenal dengan masyarakat Melayu, namun masyarakat Riau sebenarnya adalah suatu masyarakat yang penduduknya terdiri atas berbagai asal usul dan suku bangsa.Karena itu, masyarakat Riau dapat pula disebut dengan masyarakat majemuk.

Keluarga Melayu mempunyai otoritas keluarga yang terletak pada seorang ayah.Thamrin (2006) menjelaskan ayah sebagai kepala keluarga memiliki peran sebagai ketua dan merupakan orang yang paling bertanggung jawab membuat segala keputusan dalam keluarga.Otoritasnya mencakup bidang pendidikan, pengawasan terhadap anak, kewajiban rumahtangga, hal-hal yang berkaitan dengan krisis hidup (life crises), pendapatan, dan perbelanjaan keluarga. Selanjutnya, Thamrin (2006) menjelaskan seorang ibu/istri di keluarga Melayu biasanya lebih banyak menghabiskan waktu di dalam rumah, misalnya dalam mendidik anak, menjaga makan dan minum keluarga, dan melayani suami, sehingga urusan rumah tangga tidak boleh dipisahkan dari perempuan. Para istri tidak dibebankan untuk mencari penghasilan untuk keluarga.Anak-anak 
dalam keluarga Melayu memiliki peranan sesuai dengan tingkat umur dan jenis kelamin (Thamrin, 2006).

Hubungan masyarakat Melayu Riau dengan masyarakat yang berasal dari luar kelompoknya berjalan baik.Kebudayaan Melayu bersifat terbuka dan akomodatif yang juga merupakan gambaran umum dari masyarakat Melayu Riau.Peradaban Melayu menjadikan agama sebagai dasar hukum.Adat Melayu mempunyai filosofi, "Adat bersandikan syarak, syarak bersandikan kitabullah", artinya Melayu berpegang kepada kitab Allah dan sunah Nabi (Suwardi, 2007). Adat dipegang teguh oleh masyarakat Melayu, hal ini terlihat dalam pepatah, "Biar mati anak asal tidak mati adat". Ungkapan lebih lanjut, "Adat tidak lekang oleh panas dan tidak lapuk oleh hujan". Akan tetapi ada pula ungkapan, "Sekali air bah sekali tepian berubah", artinya adat yang diadatkan tidak boleh disesuaikan dengan perkembangan zaman (Suwardi, 2007). Nilai-nilai budaya merupakan pusat atau inti dari wujud kebudayaan itu sendiri. Inti dari suatu kebudayaan mencakup nilai-nilai kebudayaan yang menentukan sifat dan corak dari pikiran, cara berpikir, serta tingkah laku manusia suatu kebudayaan.

Menurut Hamdani, Nurdin, Dewi, Subarkah, \& Rinawati (2004), nilai-nilai leluhur yang tergambar dari beragam karya sastra budaya Melayu meliputi: (a) nilai kegotongroyongan, (b) nilai taat pada hukum, (c) nilai keterbukaan, (d) nilai adil dan benar, (e) nilai musyawarah dan mufakat, (f) nilai persatuan dan kesatuan, (g) nilai tenggang menenggang, (h) nilai hemat dan cermat, (i) nilai arif dan bijak, (j) nilai memanfaatkan waktu, (k) nilai amanah, (l) nilai bertanggung jawab, (m) nilai malu, (n) nilai berpandangan jauh ke depan, dan (o) nilai ilmu pengetahuan.

Selanjutnya, Suwardi (2007) menjelaskan kemajuan pendidikan pada orang Melayu di Riau telah membawa banyak perubahan dalam kebudayaannya.Diantaranya perubahan itu adalah penggunaan waktu.Masyarakat Melayu menggunakan cukup banyak waktu untuk bercengkrama dengan kerabat atau teman.Menurut Effendy (2012), keadilan dan kebenaran adalah kunci utama dalam menegakkan tuah dan marwah, mengangkat harkat dan martabat serta mendirikan daulat dan kewibawaan dalam peradaban masyarakat Melayu.Jadi, orang Melayu sangat mementingkan nilai-nilai yang menjunjung keutamaan dan kemuliaan, keadilan dan kebenaran dalam kehidupan sehari-harinya.

Berdasarkan pendapat di atas dapat disimpulkan bahwa nilai-nilai dalam budaya Melayu sangat banyak, sehingga budaya Melayu merupakan budaya yang kaya akan nilai-nilai yang baik. Nilai-nilai tersebut dijadikan pedoman bagi orangtua budaya Melayu dalam kehidupan sehari-hari dalam memberikan perhatian kepada anaknya.

Kebudayaan Jawa mempunyai kekhasannya tersendiri.Menurut Syukur (2012), kekhasan budaya Jawa yang paling menonjol adalah penggunaan simbol dalam segala aspek kehidupannya, terutama dalam beragama.Simbol dijadikan sarana atau media untuk menitipkan atau menyampaikan pesan serta nasihat-nasihat kepada manusia secara menyeluruh.Oleh sebab itu, kehidupan moral religius dijadikan pola dan filsafat hidup mereka.Hal ini tercermin pada konsep memandang alam lingkungan dan sesama manusia.Masyarakat pada kebudayaan Jawa menganut sistem kekerabatan bilateral yaitu diperhitungkan dari dua belah pihak antara ibu dan ayah.Sedangkan garis keturunan masyarakat Jawa menganut sistem kekerabatan patrilineal, yaitu sistem kekerabatan yang menarik garis keturunan dari dari ayah.

Syukur (2012) menjelaskan hubungan sosial orang Jawa dibentuk karena adanya tepo seliro, artinya mengukur kepada diri sendiri sebelum sesuatu dilakukan terhadap orang lain. Nasehat ini dapat diartikan lain bahwa jangan melakukan suatu perbuatan kepada orang lain yang tidak ingin dilakukan terhadap diri sendiri, jangan melukai perasaan orang lain, dan jangan mencampuri urusan orang lain. Sedyawati (2010) menjelaskan kepatutan perilaku yang berhubungan dengan kedudukan dan peran di dalam masyarakat sangat diperhatikan oleh orang Jawa.Sedyawati (2010) mengemukakan perilaku yang tidak tepat atau tidak patut (ora munggub) dianggap sebagai tanda kekurangan adab. Tata cara penggunaan bahasa dan penyapaan, tata cara pengambilan sikap tubuh 
dan penempatan diri, tata cara berbusana, dan lain-lain. Selain penataan lingkungan binaan, semua berfungsi sebagai sarana pembentukan, penanaman, maupun intensifikasi nilai-nilai budaya di dalam masyarakat.Nilai sentral terletak pada kepatuhan, dan hanya kepatuhanlah yang dapat menghadirkan rasa (penerimaan batin).

Keith (2011:75) menjelaskan "This culturally regulated behavior practices incorporate sleeping and feeding routines, childcare arrangement, interpersonal interaction styles and teaching". Dari pendapat tersebut dapat dipahami bahwa suatu budaya mengatur bagaimana individu bertingkah laku yang mencakup kebiasaan dan rutinitas sehari-hari, keturunan, gaya interaksi interpersonal dan mengajar yang merupakan ciri khas dari suatu kebudayaan, sehingga dapat menjadi kebiasaan sehari-hari individu tersebut.

Menurut Goode (dalam Ihromi, 2004), keberhasilan atau prestasi yang dicapai siswa dalam pendidikan tidak hanya memperlihatkan mutu dari institusi pendidikan saja, tapi juga memperlihatkan keberhasilan keluarga dalam memberikan persiapan yang baik untuk keberhasilan pendidikan anak.Berdasarkan hasil penelitian Elmirawati (2013) menjelaskaan aspirasi siswa dan dukungan orangtua mempunyai hubungan yang signifikan dengan motivasi belajar siswa.Selanjutnya, hasil penelitian Mawarsih (2013) menjelaskaan terdapat pengaruhyang signifikan antara perhatian orangtua dan motivasi belajar terhadap prestasi belajar siswa SMA Negeri Jumapolo. Berdasarkan pendapat tersebut dapat disimpulkan bahwa perhatian orangtua dan motivasi belajar siswa mempunyai peranan penting dalam meningkatkan hasil belajar siswa.

Hasil penelitian Nirwana (2003) menjelaskaan terdapat perbedaan aspirasi belajar Matematika antara laki-laki dan perempuan berdasarkan budayanya.Perbedaan aspirasi belajar Matematika tersebut terdapat pada siswa laki-laki dan perempuan yang berlatar belakang budaya Minangkabau, sedangkan pada budaya Batak tidak terdapat perbedaan aspirasi belajar antara siswa laki-laki dan perempuan.Dengan demikian dapat dipahami bahwa budaya Minangkabau dan Batak antara laki-laki dan perempuan memiliki tingkat aspirasi belajar Matematika yang berbeda.

Berdasarkan pendapat terebut, dapat disimpulkan bahwa siswa yang berlatar belakang budaya yang berbeda memiliki perbedaan dalam pencapaian hasil belajarnya.Siswa yang berlatar belakang budaya Jawa mendominasi peringkat pada setiap kelas daripada siswa berlatar belakang budaya Melayu, Minangkabau, dan Batak. Apabila dibandingkan antara siswa yang berlatar belakang budaya Melayu dan Jawa terdapat perbedaan yang sangat sedikit dalam pencapaian hasil belajarnya, sedangkan pada siswa yang berlatar belakang budaya Minang dan Batak memperoleh hasil belajar yang berbeda dengan siswa yang berlatar belakang budaya Melayu dan Jawa. Perbandingan keempat budaya tersebut sangat terlihat berdasarkan pencapaian hasil belajarnya.Jadi, dapat dipahami bahwa keberhasilan seorang siswa dalam pencapaian hasil belajarnya juga dipengaruhi oleh latar belakang budaya dalam lingkungan keluarganya.Dengan demikian perlu dilakukan penelitian lebih lanjut mengenai motivasi belajar siswa yang berlatar belakang budaya Melayu dan Jawa.Penelitian ini bertujuan untuk menguji perbedaan motivasi belajar siswa yang berlatar belakang budaya Melayu dan Jawa.

\section{KAJIAN LITERATUR}

\section{Motivasi Belajar}

\section{Pengertian Motivasi}

Motivasi dapat dikatakan sebagai daya penggerak dari dalam diri individu untuk melakukan aktivitas-aktivitas tertentu demi mencapai suatu tujuan. Sebagaimana yang dijelaskan Hamalik (2008:158) "motivasi adalah perubahan energi dalam diri seseorang yang ditandai dengan timbulnya perasaan dan reaksi untuk mencapai tujuan". Purwanto (1995:6) menjelaskan "motivasi sebagai suatu usaha yang disadari untuk menggerakkan, mengarahkan, dan menjaga tingkah laku 
seorang anak agar ia terdorong untuk bertindak melakukan sesuatu sehingga mencapai hasil atau tujuan pendidikan sesuai yang diharapkan dan ditetapkan dalam kurikulum sekolah".

Mc. Donald (dalam Hamalik, 2004:158) menjelaskan "Motivation is an energy change within the person characterized by affective arousal and antocipatory goal reaction". Berdasarkan pendapat tersebut dapat dimaknai bahwa motivasi merupakan suatu perubahan energi dalam diri atau pribadi seseorang yang ditandai dengan timbulnya perasaan dan reaksi untuk mencapai tujuan tertentu.

Menurut Sardiman (2012), motivasi dapat juga dikatakan serangkaian usaha menyediakan kondisi-kondisi tertentu, sehingga seseorang mempunyai keinginan untuk melakukan sesuatu dan seandainya tidak mempunyai keinginan, maka akan berusaha untuk meniadakan atau mengelakkan perasaan tidak suka itu. Jadi motivasi dapat juga dirangsang oleh faktor dari luar sehingga motivasi akan tumbuh di dalam diri seseorang.

Senada dengan itu, Crider (1983:118) menjelaskan "Motivation defined as the desires, needs, and interests that arouse or activate an organism and direct it toward a spesific goal, can lead to many different behaviours". Motivasi merupakan keinginan, kebutuhan, dan kepentingan yang membangkitkan atau mengaktifkan suatu organisme untuk mencapai tujuan secara spesifik dengan berbagai perilaku yang berbeda.

Poerwadarmita (1989) menjelaskan motivasi atau semangat merupakan nafsu untuk bekerja, berjuang, dan sebagainya. Berdasarkan uraian tersebut, maka dapat ditarik kesimpulan bahwa yang dimaksud dengan motivasi adalah suatu usaha yang disadari untuk menggerakkan, mengarahkan, dan menjaga tingkah laku seorang anak agar ia terdorong untuk bertindak melakukan sesuatu sehingga mencapai hasil. Motivasi ditandai oleh harapan untuk sukses dalam memecahkan masalah, tinjauan masa depan yang optimis dan prestasi akademis, dorongan sosial, dorongan aktivitas, dorongan untuk merasa aman, dorongan untuk dihargai, dan dorongan untuk dimiliki. Motivasi atau semangat adalah nafsu untuk bekerja, berjuang, dan melakukan pekerjaan secara giat dan lebih baik.

Berdasarkan uraian di atas maka dapat disimpulkan bahwa motivasi adalah suatu dorongan yang dapat menjadi serangkaian usaha untuk menyediakan kondisi-kondisi tertentu, sehingga seseorang mempunyai keinginan untuk melakukan sesuatu yang dapat bermanfaat bagi dirinya.

\section{Pengertian Motivasi Belajar}

Motivasi sebagai dasar penggerak yang mendorong aktivitas belajar. Seseorang melakukan aktivitas belajar, karena ada yang mendorongnya. Sardiman (2007) menjelaskan motivasi belajar sebagai keseluruhan daya gerak di dalam diri siswa yang menimbulkan kegiatan belajar, sehingga tujuan yang ingin dicapai oleh siswa tercapai. Motivasi belajar merupakan faktor psikis yang bersifat non intelektual. Perannya yang khas adalah dalam menumbuhkan gairah, merasa senang, dan semangat untuk belajar. Motivasi sebagai penggerak yang mendorong seseorang untuk belajar, bila seseorang sudah termotivasi untuk belajar, maka dia akan melakukan aktivitas belajar dalam rentang waktu tertentu (Musbikin, 2012).

Senada dengan itu, Winkel (1983) menjelaskan motivasi dalam kegiatan belajar dapat dikatakan sebagai keseluruhan daya penggerak di dalam diri seseorang yang menimbulkan kegiatan belajar, yang menjamin kelangsungan dari kegiatan belajar dan yang menimbulkan arah pada kegiatan belajar, sehingga tujuan yang dikehendaki oleh individu dapat tercapai

Dalam proses belajar, motivasi sangat diperlukan, seseorang yang tidak mempunyai motivasi dalam belajar tidak akan mungkin melakukan aktivitas belajar (Djamarah, 2011). Hal ini menunjukkan bahwa anak yang memiliki motivasi belajar akan dapat meluangkan waktu belajar lebih banyak dan lebih tekun dari pada mereka yang kurang memiliki atau sama sekali tidak mempunyai motivasi belajar. 
Soemanto (2003) menjelaskan motivasi belajar merupakan faktor psikis yang bersifat non intelektual yang berperan dalam menimbulkan gairah belajar serta perasaan senang dan bersemangat untuk belajar.Selanjutnya Prayitno (1989) menjelaskan bahwa motivasi belajar tidak hanya sebagai energi yang mengarahkan anak untuk belajar, tetapi juga suatu energi yang mengarahkan aktivitas siswa kepada tujuan belajar yang diharapkan. Senada dengan itu, Winkel (1983) menjelaskan motivasi belajar adalah keseluruhan daya penggerak di dalam diri siswa yang menimbulkan kegiatan belajar, menjamin kelangsungan dari kegiatan belajar.

Berdasarkan pendapat di atas, dapat disimpulkan bahwa motivasi belajar adalah suatu dorongan yang ada di dalam diri seseorang untuk belajar yang nantinya terjadi perubahan tingkah laku, yang mana perubahan ini akan mempengaruhi pola pikir inidividu dalam berbuat dan bertindak. Motivasi belajar mempunyai peranan penting dalam belajar. Tanpa adanya motivasi maka kegiatan belajar akan sulit dan berhasil dengan baik.

\section{Fungsi Motivasi}

Motivasi merupakan dorongan yang memiliki fungsi-fungsi tertentu. Hal ini diperkuat Sardiman (2012), ada tiga fungsi motivasi, yaitu (1) mendorong manusia untuk berbuat, (2) menentukan arah perbuatan, dan (3) menyeleksi perbuatan. Motivasi juga dapat berfungsi sebagai pendorong usaha untuk pencapaian prestasi. Seseorang melakukan sesuatu usaha karena adanya motivasi. Adanya suatu motivasi yang baik dalam belajar akan menunjukkan hasil yang baik juga. Senada dengan itu,

Hamalik (2001) menjelaskan bahwa motivasi mendorong timbulnya perilaku dan mempengaruhi serta dapat mengubah perilaku, jadi fungsi motivasi itu meliputi untuk mendorong timbulnya perilaku atau suatu perbuatan. Artinya, tanpa motivasi maka akan timbul suatu perbuatan seperti belajar, motivasi berfungsi sebagai pengarah. Artinya, mengarahkan perbuatan ketercapaian tujuan yang diinginkan, motivasi berfungsi sebagai penggerak. Artinya, besar kecilnya motivasi akan menentukan cepat atau lambatnya suatu pekerjaan.

Berdasarkan uraian di atas, dapat disimpulkan bahwa motivasi memiliki fungsi dalam meningkatkan hasil belajar. Dengan usaha yang tekun dan didasari dengan motivasi, maka seseorang yang belajar akan mendapatkan prestasi yang baik. Tingginya motivasi pada siswa dapat menentukan tingkat pencapaian prestasi belajarnya.

\section{Jenis-jenis Motivasi}

Motivasi terdiri dari beberapa jenis. Hamalik (2001) menjelaskan motivasi dapat dibagi menjadi dua jenis yaitu motivasi intrinsik dan motivasi ekstrinsik. Untuk lebih jelas lagi dapat diuraikan sebagai berikut.

\section{Motivasi intrinsik}

Menurut Hamalik (2001), motivasi intrinsik adalah motivasi yang tercakup di dalam situasi belajar dan memenuhi kebutuhan-kebutuhan serta tujuan-tujuan siswa. Jenis motivasi ini timbul dari dalam diri individu sendiri tanpa ada paksaan dorongan orang lain, tetapi atas dasar dan kemauan sendiri. Motivasi ini sering juga disebut motivasi murni. Motivasi yang sebenarnya timbul dalam diri siswa sendiri, misalnya keinginan untuk mendapatkan keterampilan tertentu, memperoleh informasi, dan mengembangkan sikap untuk berhasil. Jadi motivasi ini timbul tanpa pengaruh dari luar, karena rasa ingin tahunya lebih tinggi terhadap sesuatu. Jadi, motivasi intrinsik adalah motivasi yang ada dalam diri siswa yang dapat meningkatkan kemauan diri siswa dalam belajar.

\section{Motivasi ekstrinsik}

Menurut Hamalik (2001), motivasi ekstrinsik adalah motivasi yang disebabkan oleh faktor dari luar situasi belajar seperti ijazah, tingkatan hadiah, dan persaingan yang bersifat negatif dan 
hukuman. Jenis motivasi ini timbul sebagai akibat pengaruh dari luar individu, karena adanya ajakan, suruhan atau paksaan dari orang lain sehingga dengan keadaan demikian siswa memiliki keinganan untuk belajar.

Motivasi ekstrinsik diperlukan di sekolah. Siswa yang belum memiliki kesadaran mengenai pentingnya belajar, perlu diberikan motivasi oleh guru, sehingga siswa mempunyai keinginan untuk belajar. Tugas guru adalah membangkitkan motivasi siswa untuk menanamkan keinginan dalam belajar. Banyak usaha dan cara yang dapat dilakukan oleh guru untuk memotivasi siswa. Bagi siswa yang tidak memiliki motivasi dalam dirinya, maka motivasi ekstrinsik merupakan dorongan dari luar dirinya sangat diperlukan.

Senada dengan itu, Noordhoorn (2010) menjelaskan dua jenis motivasi yaitu intrinsic motivation dan extrinsic motivation.Penjelasan lebih lanjut dapat diuraikan sebagai berikut.

\section{Intrinsic motivation}

Noordhoorn (2010:14) menjelaskan sebagai berikut; Intrinsic motivation is not initiated by a reward from somebody else, but intrinsic motivation appears as a person strives to get a good feeling about himself or when the task is regarded as interesting. It follows that the intrinsic motivation of an individual cannot be affected directly, but it may be possible to ensure that the intrinsic motivation can be stimulated in an indirect way.Berdasarkan pendapat tersebut, dapat dipahami bahwa motivasi intrinsik tidak dipengaruhi oleh hadiah dari orang lain, tetapi muncul sebagai pemuasan rasa bahagia ketika telah menyelesaikan suatau aktivitas. Oleh karena itu, motivasi intrinsik seseorang tidak dapat dipengaruhi secara langsung dari luar, tetapi motivasi intrinsik dapat dirangsang secara tidak langsung.

\section{Extrinsic motivation}

Noordhoorn (2010:14) menjelaskan sebagai berikut: Extrinsic motivation is the opposite of internal motivation, what means that the incentive to take action takes place outside the individual himself. The stimulus to take action can be material in monetary or nonmonetary form, or it can be immaterial.Dari Pendapat tersebut, dapat dipahami bahwa motivasiektsrinsikmerupakan kebalikan darimotivasi intrinsik. Hal ini berarti bahwainisiatif untukmengambil tindakanterjadi di luarindividu itu sendiri. Stimulusuntuk mengambil tindakan berasal dari luar diri individu tersebut dapat berupa material atau nonmaterial.

Berdasarkan beberapa pendapat tersebut, dapat disimpulkan bahwa motivasi intrinsik siswa dalam belajar adalah dorongan yang ada dalam diri siswa dalam meningkatkan keinginan atau kemauannya dalam belajar. Sedangkan motivasi ekstrinsik siswa dalam belajar adalah dorongan dari luar diri siswa baik itu keluarga, teman dan guru serta semua lingkungan yang dapat meningkatkan keinginan atau kemauan dalam belajar. Kedua motivasi ini sangat berpengaruh dalam meningkatkan hasil belajar.

\section{Faktor-faktor yang Mempengarubi Motivasi Belajar}

Motivasi belajar merupakan dorongan dari dalam diri atau luar diri yang merupakan suatu objek tertentu yang dipengaruhi oleh beberapa faktor. Syah (2012) menjelaskan faktor-faktor yang mempengaruhi motivasi belajar siswa dapat kita bedakan menjadi tiga macam meliputi: (1) faktor internal, (2) faktor pendekatan belajar, (3) faktor eksternal.

Senada dengan itu, Dimyati \& Mudjiono (2009) menjelaskan faktor-faktor yang dapat mempengaruhi motivasi belajar meliputi: (1) cita-cita dan aspirasi, (2) kondisi siswa, (3) kemampuan belajar, (4) kondisi lingkungan sosial dan budaya siswa, unsur-unsur dinamis dalam belajar, dan (5) upaya guru dalam mengajarkan siswa. 
Selanjutnya Elliott, Kratochwill, Cook, \& Travers (1996:342) menjelaskan "Given the importance of motivation to learning, you should be aware of several of the must crucial influences on motivation. Among them are anxiety, attitudes, curiosity, locus of control, learned helplessness, self efficacy, and finally cooperative learning". Berdasarkan pendapat tersebut, dapat dipahami bahwa terdapat beberapa hal penting yang secara langsung ataupun tidak langsung mempengaruhi motivasi, diantaranya adalahkecemasan, sikap, rasa ingin tahu, locus of control, belajarketidakberdayaan, kemampuan diri, dan pembelajarankooperatif.

Menurut Majid (2013) faktor-faktor yang mempengaruhi motivasi ada dua, yang berasal dari dalam dan luar diri individu. Faktor yang berasal dari dalam meliputi: (1) adanya kebutuhan, (2) persepsi individu mengenai dirinya, (3) harga diri dan prestasi, (4) Adanya cita-cita dan harapan masa depan, (5) keinginan tentang kemajuan diri, (6) minat, dan (7) kepuasan kinerja. Faktor yang berasal dari luar meliputi: (1) pemberian hadiah, (2) kompetisi, (3) hukuman, (4) pujian, (5) situasi lingkungan pada umumnya, (6) sistem imbalan yang diterima.

Berdasarkan paparan di atas, dapat disimpulkan bahwa banyak faktor yang mempengaruhi motivasi belajar antara lain: (1) internal, (2) pendekatan belajar, (3) eksternal. Sehingga dari ketiga faktor tersebut sangat mempengaruhi tinggi atau rendahnya motivasi siswa dalam belajar di sekolah.Ketiga faktor tersebut mencakup semua faktor-faktor mempengaruhi dalam meningkatkan motivasi belajar siswa.

\section{Kaitan Budaya dengan Motivasi Belajar}

Menurut Samovar, Porter, \& McDaniel (2010) budaya mempengaruhi cara seseorang berhubungan dengan orang lain, bertingkah laku, dan memandang dunia. Fordham \& Ogbu; Fryer \& Torelli (dalam Center on Education Policy, 2012:5) menjelaskan "That a desire to maintain a distinct cultural identity in opposition to the dominant group can negatively affect academic motivation most notably, when high-achieving African American students are accused by their peers of acting white". Graham dan HudleyTorelli (dalam Center on Education Policy, 2012:5) menjelaskan sebagai berikut. Several studies have explored how social and cultural context can have a bearing on students' motivations or aspirations. For example, some researchers assert that experiences with or perceptions of discrimination can damage the confidence of students of color and contribute to academic disengagement".Berdasarkan pendapat tersebut, dapat dipahami bahwa suatu keinginan untukmempertahankanidentitas budayayang berbedadapatmempengaruhi motivasibelajardan aspirasi belajar siswa.

Gannon \& Newman (dalam Noordhoorn, 2010:19), menjelaskan "Argue that a considerable amount of research indicates that culture often plays a significant role in determining who is rewarded and how. As seen, the type of organisational culture determines the employee's behavior in the organisation". Berdasarkan pendapat tersebut, dapat dipahami bahwa budaya penting dalam menentukan cara bersikap seseorang. Perilaku yang dilakukan seseorang akan berbeda dengan orang lain yang berasal dari budaya berbeda. Hal ini disebabkan oleh penetapan nilai-nilai yang dilakukan budaya terhadap tersebut.

Sebagian besar kelompok budaya dan etnis menempatkan nilai yang tinggi pada pendidikan.Namun, pada tingkat tertentu kelompok budaya yang berbeda tampaknya mendorong nilai yang berbeda pula berkenaan dengan pembelajaran di sekolah (Ormrod, 2014). Jadi, dapat disimpulkan bahwa budaya mempengaruhi motivasi belajar seseorang, motivasi yang diperlihatkan seseorang akan berbeda dengan orang lain yang berasal dari budaya yang berbeda.

\section{METODOLOGI}

Penelitian ini menggunakan metode kuantitatif jenis deskriptif dan studi komparatif. Populasi penelitian ini adalah siswa SMP Negeri 1 Siak Hulu Kabupaten Kampar berjumlah 399 orang, dan sampel berjumlah 200 orang, yang dipilih dengan rumus Slovin dan dilanjutkan dengan 
teknik simple random sampling. Instrumen yang digunakan adalah model skala Likert. Skala motivasi belajar (reliabilitas 0.905).Data dianalisis dengan statistik deskriptif dan Multivariate Analysis of Variance (MANOVA).

\section{TEMUAN}

\section{Deskripsi Data}

Data dalam penelitian ini meliputi variabel budaya (X), motivasi belajar (Y). Berikut inidikemukakan deskripsi data hasil penelitian.

\section{Motivasi BelajarSiswa yang Berlatar Belakang Budaya Melayu}

Data motivasi belajar yang berlatar belakang budaya Melayu diperoleh dari sampel (responden) yang berasal dari SMP Negeri 1 Siak Hulu yang keluruhannya berjumlah 117 orang siswa. Item pernyataan pada variabel motivasi belajar sebanyak 30 item, rentang skor dari 1-5, skor tertingginya adalah 150, dan skor terendah adalah 30. Deskripsi data perhatian orangtua yang berlatar belakang budaya Melayu dapat dilihat pada Tabel 1 berikut.

Tabel 1. Distribusi Frekuensi dan Kategori Skor Perhatian Orangtua terhadap Kegiatan Siswa yang Berlatar Belakang Budaya Melayu dalam Perspektif Gender $(n=117)$

\begin{tabular}{cccc}
\hline Interval Skor & Kategori & Ferekuensi & $\mathbf{( \% )}$ \\
$\geq 126$ & Sangat Tinggi (ST) & 47 & 40.17 \\
$102-125$ & Tinggi (T) & 61 & 52.13 \\
$78-101$ & Sedang (S) & 9 & 7.70 \\
$54-77$ & Rendah (R) & 0 & 0 \\
$\leq 53$ & Sangat Rendah (SR) & 0 & 0 \\
\hline
\end{tabular}

Berdasarkan Tabel 1, sebagian besar siswa memiliki motivasi belajar tinggi yaitu sebesar $52.13 \%$, 40.17\% siswa memiliki motivasi belajar sangat tinggi, 7.70\% siswa memiliki motivasi belajar yang sedang. Selanjutnya, secara rinci deskripsi motivasi belajar berdasarkan sub variabel yang dapat dilihat pada Tabel 2 berikut. 
Tabel 2. Deskripsi Rata-rata (Mean) dan Persentase Motivasi Belajar Siswa yang Berlatar Belakang Budaya Melayu Berdasarkan Sub Variabel

\begin{tabular}{|c|c|c|c|c|c|c|c|c|}
\hline \multirow[t]{2}{*}{ Sub variabel } & \multicolumn{8}{|c|}{ Skor } \\
\hline & Ideal & Max & Min & Total & Rata-raa & $\%$ & Sd & K \\
\hline $\begin{array}{l}\text { Ketekunan dalam } \\
\text { belajar (14 butir } \\
\text { item) }\end{array}$ & 70 & 69 & 44 & 6877 & 58.78 & 83.97 & 6.012 & $\mathbf{T}$ \\
\hline $\begin{array}{l}\text { Ulet dalam } \\
\text { menghadapi } \\
\text { kesulitan belajar ( } 5 \\
\text { butir item) }\end{array}$ & 25 & 25 & 15 & 2307 & 19.72 & 78.88 & 2.442 & $\mathbf{T}$ \\
\hline $\begin{array}{l}\text { Ketekunanmengerj } \\
\text { akan tugas (11 } \\
\text { butir item) }\end{array}$ & 55 & 53 & 30 & 5015 & 42.86 & 77.45 & 5.532 & $T$ \\
\hline Keseluruhan (30) & 150 & 140 & 98 & 14199 & 121.39 & 80.10 & 12.104 & $\mathbf{T}$ \\
\hline
\end{tabular}

Berdasarkan Tabel 2, dapat diketahui bahwa secara keseluruhan motivasi belajar siswa yang berlatar belakang budaya Melayu berada pada kategori tinggi dengan skor ideal adalah 150, siswa yang mendapat skor motivasi belajar yang tertinggi adalah 140, siswa yang mendapat skor motivasi belajar yang terendah adalah 98. Secara keseluruhan skor total yang diperoleh yaitu 14199 dengan rata-rata skor yang diperoleh siswa yaitu 121.39 atau $80.10 \%$ dari skor ideal dengan standar deviasi 12.104. Dengan demikian secara rata-rata motivasi belajar siswa yang berlatar belakang budaya Melayu berada pada kategori tinggi $(\mathrm{T})$.

Lebih rinci dapat diketahui bahwa sub variabel ketekunan dalam belajar, dengan skor ideal 70 , skor tertinggi yaitu 69 dan skor terendah yaitu 44. Secara keseluruhan skor total sub variabel ketekunan dalam belajar yang diperoleh yaitu 6877 dengan rata-rata yang diperoleh siswa yaitu 58.78 atau $83.97 \%$ dari skor ideal dengan standar deviasi 6.012. Dengan demikian secara rata-rata motivasi belajar siswa yang berlatar belakang budaya Melayu pada sub variabel ketekunan dalam belajar berada pada kategori tinggi ( $\mathrm{T}$ ).

Selanjutnya, pada sub variabel ulet dalam menghadapi kesulitan belajar, dengan skor ideal 25 , skor tertinggi yaitu 25 dan skor terendah yaitu 15 . Secara keseluruhan skor total sub variabel ulet dalam menghadapi kesulitan belajar diperoleh yaitu 2307 dengan rata-rata yang diperoleh siswa yaitu 19.72 atau $78.88 \%$ dari skor ideal dengan standar deviasi 2.442. Dengan demikian secara rata-rata motivasi belajar siswa yang berlatar belakang budaya Melayu pada sub variabel ulet dalam menghadapi kesulitan belajar berada pada kategori tinggi ( $\mathrm{T})$.

Kemudian, pada sub variabel ketekunan mengerjakan tugas, dengan skor ideal 55, skor tertinggi yaitu 53 dan skor terendah yaitu 30. Secara keseluruhan skor total sub variabel ketekunan mengerjakan tugas diperoleh yaitu 5015 dengan rata-rata yang diperoleh siswa yaitu 42.86 atau $77.45 \%$ dari skor ideal dengan standar deviasi 5.532. Dengan demikian secara rata-rata motivasi belajar siswa yang berlatar belakang budaya Melayu pada sub variabel ketekunan mengerjakan tugas berada pada kategori tinggi $(\mathrm{T})$.

Selanjutnya, deskripsi motivasi belajar siswa yang berlatar belakang budaya Melayu berdasarkan item masing-masing dalam indikatornya yaitu 9 item berada pada kategori sangat tinggi (30\%), 20 item berada pada kategori tinggi (66.66\%), dan 1 item berada pada kategori sedang $(3.333 \%)$ 


\section{UJI PERSYARATAN ANALISIS}

Pengujian normalitas data dengan menggunakan teknik analisis Kolmogorov-Smirnov dengan koreksi Liliefors, menggunakan ketetapan alpha $(\alpha)$ 0.05. Berdasarkan pengolahan data diperoleh hasil Asymp.Sig lebih besar dari 0.05, ini berarti data motivasi belajar siswa ditinjau dari latar belakang budaya berdistribusi normal. Selanjutnya, hasil pengujian homogenitas dilakukan dengan Uji Box's $M$. Jika nilai $P$-value $>0.05$, maka hipotesis diterima sehingga disimpulkan matriks varians-kovarians dari populasi adalah sama atau homogen. Hasil uji tersebut diperoleh motivasi belajar antara siswa berlatar belakang budaya Melayu dan Jawa memiliki P-value lebih besar dari 0.05 , sehingga asumsi homogenitas varians terpenuhi. Hal ini berarti matriks varians-kovarians pada tabel tersebut adalah sama/homogen untuk kesemua grup varians.

\section{Perbedaan Motivasi Belajar Siswa yang Berlatar Belakang Budaya Melayu}

Hasil pengujian perbedaan pada variabel budaya yaitu budaya Melayu dan Jawa pada motivasi belajar melalui MANOVA dapat dilihat dalam Tabel 3 sebagai berikut.

Tabel 3. Tests of Between Subjects Effects Moitivasi Belajar Siswa yang Berlatar Belakang Budaya Melayu dan Jawa

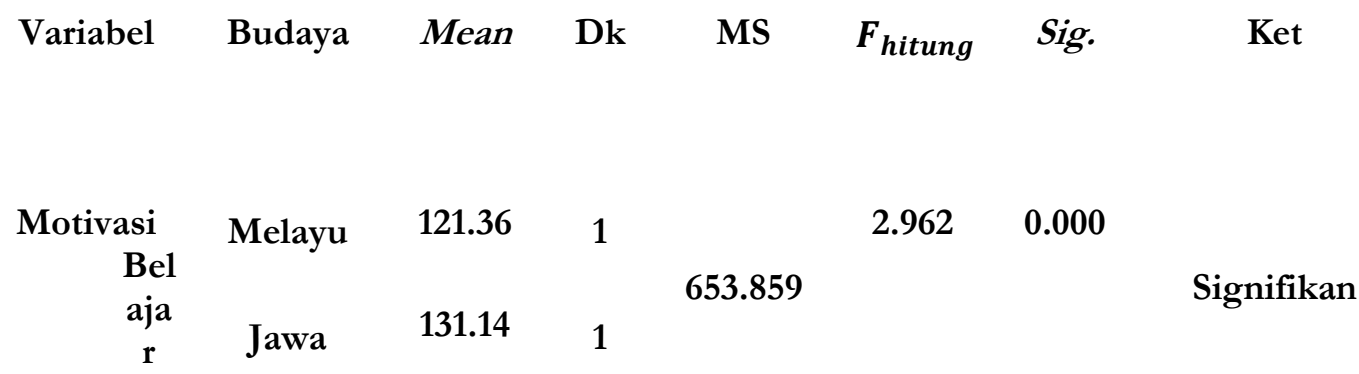

Berdasarkan Tabel 6 di atas, dapat dipahami bahwa motivasi belajar antara siswa yang berlatar belakang budaya Melayu dan Jawa memiliki perbedaan yang signifikan.

\section{DISKUSI}

Temuan penelitian memperlihatkan bahwa motivasi belajar siswa yang berlatar belakang budaya Melayu pada kategori tinggi (T) dan Jawa terletak pada kategori sangat Tinggi (ST). Sebagian besar kelompok budaya dan etnis menempatkan nilai yang tinggi pada pendidikan, namun pada tingkat tertentu kelompok budaya yang berbeda tampaknya mendorong nilai yang berbeda pula berkenaan dengan pembelajaran di sekolah (Ormrod, 2014).

Hasil penelitian Murdani (2000) mengemukakan bahwa untuk menciptakan motivasi belajar yang kuat, guru harus mampu memilih strategi pembelajaran yang sesuai dengan sifat pesan yang disampaikan serta kemampuan masing-masing siswa. Melalui strategi yang tepat siswa akan terdorong dan bersemangat dalam belajar.Ketekunan dalam belajar dan tugas hal yang dilakukan siswa salah satu contohnya adalah siswa tersebut dapat bekerja terus menerus dalam waktu yang lama, jika pekerjaannya dalam belajar belum selesai maka siswa tersebut tidak pernah berhenti. Hal ini sangat diharuskan bagi siswa dalam belajar, karena jika hal itu tidak ada dalam diri siswa maka kesuksesan dalam belajar tidak akan tercapai.

Keuletan dalam belajar sangat diperlukan untuk mencapai hasil belajar yang baik.Ulet dalam artian siswa tidak mudah putus asa dalam kesulitan apapun. Jika menghadapi kesulitan siswa yang ulet akan berusaha mencari cara untuk mengatasinya. Siswa yang sudah mampu mengatasi kesulitan dalam belajar, harus disertai oleh minat yang tinggi dalam belajar.Minat atau ketertarikan 
dalam belajar juga merupakan hal awal yang bisa membawa siswa untuk mencapai kesuksesan.Agar kesuksesan siswa tercapai juga diperlukan kemandirian dalam belajar, karena dengan adanya kemandirian dalam belajar ini dapat membantu siswa untuk mendapatkan hasil dan nilai positif bagi dirinya dengan usaha yang dilakukannya.

Siswa yang termotivasi dalam belajar akan terus menerus belajar walaupun guru meninggalkan kelas, mengerjakan tugas tambahan, tidak mau membuang waktu, aktif mengerjakan pekerjaan sekolah di luar jam pelajaran dan mencari aktifitas yang berkaitan dengan belajar. Menurunnya motivasi belajar pada siswa akan menyebabkan individu kurang bersemangat untuk mengikuti proses pembelajaran. Mood dan konsentrasi adalah suatu komponen yang penting diperlukan untuk aktivitas, minat, dan motivasi belajar pada siswa. Siswa yang malas belajar akan mempengaruhi motivasi belajar dan prestasi belajar. Namun, apabila siswa tidak mengurangi tindakan yang tidak perlu, maka hal ini akan mengganggu pikiran dan konsentrasi untuk belajar (Syah, 2012).

Motivasi merupakan hal yang perlu diperhatikan dalam kegiatan belajar siswa termasuk dalam hubungannya dengan perhatian orangtua di rumah. Menurut Hamalik (2008), motivasi dipandang berperan dalam belajar karena motivasi mengandung nilai-nilai sebagai menentukan tingkat berhasil atau gagalnya kegiatan siswa, belajar tanpa motivasi sulit untuk mencapai keberhasilan secara optimal, pembelajaran yang bermotivasi pada hakikatnya adalah pembelajaran yang sesuai dengan kebutuhan, dorongan, motif, dan minat yang ada pada diri siswa, pembelajaran yang bermotivasi menuntut kreativitas dan imajinatif guru untuk berupaya sungguh-sungguh mencari cara-cara yang relevan dan serasi guna membangkitkan serta memelihara motivasi belajar siswa, berhasil atau gagalnya dalam membangkitkan dan mendayagunakan motivasi dalam proses pembelajaran berkaitan dengan upaya pembinaan disiplin kelas. Masalah disiplin kelas dapat timbul karena kegagalan dalam penggerakan motivasi belajar, penggunaan asas motivasi merupakan sesuatu yang esensial dalam proses belajar dan pembelajaran. Motivasi menjadi salah satu faktor menentukan pembelajaran yang efektif.

Selanjutnya, Purwanto (2010) mengemukakan bahwa siswa yang mempunyai motivasi belajar tinggi mempunyai ketekunan dan kesabaran seperti belajar dengan penuh hati-hati, cermat dan teliti, selalu berusaha dalam belajar dengan penuh konsentrasi, dan mempunyai kedisiplinan yang tinggi, mempunyai semangat dan kegairahan belajar seperti memiliki kemauan yang tinggi, memiliki kesenangan yang mendalam terhadap pelajaran, melakukan kegiatan yang berguna, suka tatangan, ingin menguji kemampuannya, dan berupaya mendapatkan hasil belajar yang tinggi, mempunyai tanggung jawab seperti mengerjakan tugas dengan baik, berani menanggung resiko jika salah aktif dalam belajar, dapat menyelesaikan tugas sendiri walaupun mendapatkan kesulitan belajar, dan lebih senang bekerja secara mandiri.

Siswa yang memiliki motivasi yang kuat cenderung bisa menyesuaikan diri dengan baik.Sejalan dengan hal itu. Sardiman (2011) menjelaskan 3 fungsi motivasi yaitu: mendorong siswa untuk berbuat, sebagai penggerak/motor untuk melepaskan energi. Motivasi dalam hal ini merupakan motor penggerak dari setiap kegiatan yang akan dikerjakan. Menentukan arah perubahan, yakni ke arah tujuan yang hendak dicapai.Motivasi dapat memberikan arah dan kegiatan yang harus dikerjakan sesuai dengan rumusan tujuan.Menyeleksi perbuatan, yakni menentukan perbuatan-perbuatan yang harus dikerjakan serasi guna mencapai tujuan.

Menurut Fordham \& Ogbu; Fryer \& Torelli (dalam Center on Education Policy, 2012:5) "That a desire to maintain a distinct cultural identity in opposition to the dominant group can negatively affect academic motivation most notably, when high-achieving African American students are accused by their peers of acting white".

Selanjutnya Graham dan HudleyTorelli (dalam Center on Education Policy, 2012:5) menjelaskanSeveral studies have explored how social and cultural context can have a bearing on students' motivations or aspirations. For example, some researchers assert that experiences with or perceptions of 
discrimination can damage the confidence of students of color and contribute to academic disengagement". Berdasarkan pendapat tersebut, dapat dipahami bahwa suatu keinginan untukmempertahankanidentitas budayayang berbedadapatmempengaruhi motivasibelajar siswa.Gannon \& Newman (dalam Noordhoorn, 2010:19), menjelaskan "Argue that a considerable amount of research indicates that culture often plays a significant role in determining who is rewarded and how. As seen, the type of organisational culture determines the employee's behavior in the organisation". Berdasarkan pendapat tersebut, dapat dipahami bahwa budaya penting dalam menentukan cara bersikap seseorang. Perilaku yang dilakukan seseorang akan berbeda dengan orang lain yang berasal dari budaya berbeda. Hal ini disebabkan oleh penetapan nilai-nilai yang dilakukan budaya terhadap tersebut. Jadi, dapat disimpulkan bahwa motivasi yang diperlihatkan seseorang akan berbeda dengan orang lain yang berasal dari budaya yang berbeda.

Berdasarkan hasil analisis deskriptif menunjukkan bahwa motivasi belajar siswa yang berlatar belakang budaya Melayu berada pada kategori tinggi ( $\mathrm{T}$ ) dan motivasi belajar siswa yang berlatar belakang budaya Jawa berada pada kategori sangat tinggi (ST).Dengan hasil penelitian tersebut, perlu ditindaklanjuti oleh Guru BK untuk meningkatkan motivasi belajar siswa yang berlatar belakang budaya Melayu dan mempertahankan motivasi belajar siswa yang berlatar belakang budaya Jawa.Indikator yang perlu ditingkatkan bagi siswa yang berlatar belakang budaya Melayu adalah semua indikator dalam instrumen penelitian agar memiliki motivasi belajar yang sangat tinggi. Sedangkan Indikator yang perlu ditingkatkan bagi siswa yang berlatar belakang budaya Jawa adalah konsentrasi dalam belajar, tidak mudah putus asa dalam belajar, tertantang dalam menghadapi kesulitan belajar, tabah dalam mengerjakan tugas, dan menemukan sumber yang baru .

Indikator-indikator yang tinggi maka motivasi belajar siswa akan menjadi sangat tinggi. Cara untuk meningkatkan dan mempertahankan motivasi tersebut, Guru BK bisa dengan memberikan layanan seperti bimbingan kelompok dan layanan informasi, sehingga siswa yang berlatar belakang budaya Melayu dapat meningkatkan motivasi belajarnya dan yang berlatar belakang budaya Jawa dapat mempertahankan motivasi belajarnya. pada penelitian ini implikasi pelayanan BK lebih difokuskan pada bidang pengembangan belajar.

Berdasarkan test between subjek effect ini menunjukkan bahwa motivasi belajar terdapat perbedaan yang signifikan antara siswa yang berlatar belakang Budaya Melayu dan Jawa. Perbedaan pada motivasi belajar terlihat dari skor nilai rata-rata pada semua variabel. Dilihat dari keseluruhan variabel dependen yang menunjukkan bahwa siswa berlatar belakang budaya Jawa memiliki skor nilai rata-rata motivasi belajar yang tinggi dibandingkan dengan siswa yang berlatar belakang budaya Melayu.

Tingginya skor nilai rata-rata siswa berlatar belakang budaya Jawa dipengaruhi oleh latar belakang budaya yang dimiliki. Roqib (2007) menjelaskan dalam konteks pendidikan bahwa kondisi lingkungan seseorang mempengaruhi efektivitas pendidikan dan kehidupan seseorang di masa datang.Pada masyarakat berlatar belakang budaya Jawa pendidikan menjadi fokus pengembangan Sumber Daya Manusia (SDM).

Transmigrasi telah melahirkan SDM yang sangat potensial dan spektakuler.Adanya perubahan lingkungan hidup buatan yang ditemui transmigran ditempatnya yang baru, menuntut mereka untuk dapat mengembangkan strategi adaptasi dan kemampuan beradaptasi yang tinggi.Pada Undang-undang No. 3 tahun 1972 tentang Ketentuan-ketentuan Pokok Transmigran menjelaskan bahwa tujuan penyelenggaraan transmigrasi, yaitu: (a) peningkatan taraf hidup, (b) pembangunan daerah, (c) keseimbangan penyebaran penduduk, (d) pembangunan yang merata di seluruh Indonesia, (e) pemanfaatan sumber-sumber alam dan tenaga manusia, (f) kesatuan dan persatuan bangsa, dan (g) memperkuat pertahanan dan keamanan nasional.

Undang-undang tersebut dapat disimpulkan bahwa transmigrasi digunakan untuk meningkatkan SDM termasuk di daerah transmigran. Selain itu, May (2006) menjelaskan bahwa 
salah satu kriteria yang ditetapkan oleh Direktorat Jenderal Transmigrasi mengenai calon transmigran adalah mereka yang bermotivasi tinggi. Dengan demikian, tidak heran jika penduduk transmigran Jawa mampu memanfaatkan daerah Provinsi Riau yang kini menjadi sumber penghasilan mereka.

Budaya Jawa bertransmigrasi keluar pulau Jawa. Mereka telah berakulturasi dengan budaya setempat, bentuk akulturasi pada masyarakat transmigran Jawa adalah masyarakat transmigran Jawa diposisikan sebagai orang Melayu. Salah satu tempat tujuan penduduk suku Jawa adalah di Provinsi Riau.Penduduk transmigran Jawa dipindahkan untuk memanfaatkan ladang tidur yang terhampar luas di Provinsi Riau sekaligus membuka lapangan kerja baru bagi penduduk setempat.

Setelah tiba di Riau dan dibagi berdasarkan daerah yang telah ditentukan pemerintah, tentu terdapat perbedaan perilaku dan budaya dari penduduk transmigran (Jawa) dengan budaya setempat (Melayu).Namun, sampai saat ini kekentalan adat Jawa masih sangat melekat pada masyarakat transmigran Jawa meskipun sudah lama menetap di Provinsi Riau.Ini dibuktikan dengan bahasa yang digunakan dalam keseharian di daerah transmigran, yaitu dengan menggunakan bahasa Jawa. Bahkan logat dan gaya bahasa orang Jawa yang medok masih jelas. Selain itu, kebudayaan Jawa yang masih sangat melekat pada masyarakat Jawa di daerah transmigran adalah pesta adat, terutama pesta adat pernikahan (Koentjaraningrat, dalam Roqib, 2007).

Masyarakat Jawa yang ada di Riau merupakan masyarakat pendatang/rantau.Bagusnya SDM masyarakat Jawa dipengaruhi juga dari pola merantau.Merantau adalah tipe khusus dari migrasi dengan konotasi budaya tersendiri (Naim, 1984). Migrasi juga disebut dengan urbanisasi yang merupakan suatu cara yang dicoba manusia untuk lari dari kemiskinan. Merantau sering dianggap sebagai bagian kebudayaan suku-suku bangsa Indonesia walaupun tujuan dan tingkat intensitas merantau antara satu kelompok etnik berbeda dengan etnik lainnya.

Merantau pada penduduk transmigran Jawa merupakan bagian dari teori migrasi dorongtarik (push-pull theory). Teori menegaskan ada 4 faktor yang berpengaruh terhadap seseorang dalam mengambil keputusan untuk merantau (migrasi): (1) faktor-faktor yang terdapat di daerah asal, (2) faktor-faktor yang terdapat di daerah tujuan, (3) faktor-faktor rintangan, (4) faktor pribadi. Transmigrasi merupakan merantau dikarenakan faktor-faktor yang disebabkan oleh daerah asal dan faktor-faktor yang terdapat di daerah tujuan.

Di samping itu, faktor pribadi dan rintangan juga termasuk pada migrasi ini, hal ini diperkuat pada faktor pribadi yakni masyarakat Jawa yang bertransmigrasi ke Riau ingin meningkatkan kesejahteraan dan mengubah hidup ke kehidupan yang layak yang tidak didapatkan di daerah asal.Oleh karena itu, orang-orang yang hidup di daerah rantau memiliki semangat yang tinggi untuk kelangsungan dan kesejahteraan hidup yang lebih layak dari tempat asal mereka. Hal ini didukung oleh hasil temuan Pelly (1998) menjelaskan bahwa pada umumnya perantau dari berbagai latar belakang budaya bersaing dalam mengembangkan pendidikan yang memberikan mereka akses kepada pekerjaan-pekerjaan yang baru dalam perantauan.

Orang-orang Jawa memiliki sikap hidup menerima dan pasrah yang positif (nrima ing pandum). Konsep nrima, sebenarnya tidak berarti menerima secara pasif, tetapi benar-benar menerima pada sesuatu yang tak terelakan. Jadi, seseorang dapat memulai sesuatu yang baru, bangkit lagi dan kerja keras untuk maju ke depan tanpa dibebani oleh kenangan lama, oleh hal negatif yang pernah terjadi pada dirinya (Roqib, 2007). Sebagaimana yang telah disebutkan, pasrah yang positif berarti pasrah yang diimbangi dengan kerja keras dan terus berusaha mencari yang terbaik dan paling berkualitas.

Perbedaan antara Melayu dan Jawa diduga disebabkan karena mereka adalah pendatang/perantau (transmigran), mau tidak mau mereka harus berjuang dan menjalani hidup secara layak di daerah orang.Harapan meraka untuk menjalani hidup secara layak diiringi dengan 
berbagai usaha, tanpa usaha yang sungguh-sungguh mereka belum tentu dapat memenuhi kebutuhan mereka dengan baik, walaupun pemerintah telah memberikan fasilitas, tapi itu tidak diperkirakan hanya cukup untuk beberapa tahun bukan untuk waktu panjang. Sebagian dari usaha mereka yaitu belajar, karena belajar akan memberikan akses kepada pekerjaaan yang akan datang. Sedangkan siswa yang berasal dari latar belakang budaya Melayu yang disebut juga dengan masyarakat pribumi, mempunyai motivasi belajar yang lebih rendah dibandingkan siswa berlatar belakang budaya Jawa.Diduga disebabkan karena keadaan mereka yang hidup di kampung halaman/daerah asal, yaitu di lokasi daerah Riau yang dikenal memiliki SDA yang cukup besar.

Masyarakat yang berasal dari latar belakang budaya Melayu di Riau umumnya memiliki tanah dan lahan yang besar dan berpotensi untuk menghasilkan ekonomi yang baik dan diperkirakan beberapa keturunan masih bisa untuk menghidupi anak cucu mereka. Kondisi demikian dapat mempengaruhi pemahaman dan kesadaran yang menganggap ilmu pengetahuan itu tidak terlalu penting bagi kehidupan mereka. Selanjutnya, karena mereka akan memperoleh warisan dari orangtua mereka untuk kelangsungan hidup mereka di masa yang akan datang.

\section{KESIMPULAN}

Berdasarkan temuan dan pembahasan hasil penelitian, dapat dikemukakan kesimpulan terdapat perbedaan yang signifikan motivasi belajar siswa yang berlatar belakang budaya Melayu dan Jawa. Siswa yang berlatar belakang budaya Melayu berada pada kategori tinggi, sedangkan siswa yang berlatar belakang budaya Jawa berada pada kategori sangat tinggi.

\section{SARAN}

Berdasarkan hasil-hasil penelitian, pembahasan, dan kesimpulan yang telah dikemukakan, maka untuk meningkatkan prestasi belajar siswa ada beberapa saran yang dapat direkomendasikan sebagai tindak lanjut dari penelitian ini. Beberapa saran yang dapat diajukan adalah sebagai berikut.

\section{Bagi Guru BK di sekolah}

Kepada Guru BK disarankan untuk meningkatkan motivasi belajar siswa, terutama siswa yang berlatar belakang budaya Melayu, karena siswa yang berlatar belakang budaya Melayu memilki motivasi yang rendah dibandingkan dengan siswa yang berlatar belakang budaya Jawa.

\section{Bagi Guru Mata Pelajaran}

Guru mata pelajaran disarankan dapat bekerjasama dengan Guru BK dalam meningkatkan motivasi belajar siswa. Hal tersebut bisa dilakukakn dengan selalu berkonsultasi dengan Guru BK mengenai masalah yang dihadapi siswa dalam belajar, selain itu cara untuk meningkatkan motivasi belajar siswa bisa dengan memberikan tugas-tugas yang tidak terlalu sulit dan tugas yang tidak terlalu mudah, memberikan hadiah kepada siswa yang memilki berprestasi, dan mengurangi hukuman yang dapat membuat siswa tidak termotivasi dalam belajar..

\section{Bagi peneliti lainnya}

Perlu dilakukan penelitian dengan menggunakan sampel yang lebih luas lagi dan mempertimbangkan jenis pekerjaan orangtua dan status ekonomi keluarga dengan memasukkan kalangan ekonomi menengah ke atas.

\section{DAFTAR RUJUKAN}


Berry, J. W., Poortinga, Y. H., Segall, M. H., \& Dasen, P. R. 2002. Cross Cultural Psychology. Cambridge: Cambridge University Press.

Center on Education Policy. 2012. Graduate School of Education and Human Development. Washington, D.C: Pennsylvania Avenue NW.

Crider, A. B. 1983. Psychology. America: Printed In The United States of America.

Dimyati \& Mudjiono. 2009. Belajar dan Pembelajaran. Jakarta: Rineka Cipta.

Djamarah, S. B. 2011. Psikologi Belajar. Jakarta: Rineka Cipta.

Djamarah, S. B. 2013. Pola Asub Orangtua dan Komunikasi dalam Keluarga. Jakarta: Rineka Cipta.

Effendy, T. 2012. Tunjuk Ajar Melayu. Riau: Dinas Kebudayaan dan Pariwisata.

Elliott, S. N., Kratochwill, T. R., Cook, J. L., \& Travers, J. R. 1996. Educational Psychology: Effective teaching, effective learning. USA: Times Mirror Higher Education Group Inc.

Elmirawati.2013.Hubungan antara Aspirasi Siswa dan Dukungan Orangtua dengan Motivasi Belajar serta Implikasinya terhadap Bimbingan Konseling.Jurnal Bimbingan dan Konseling, 2 (1): 107-113. (Online,) (http://journal unnes. ac. id/sju/index. php/epj), diakses Desember 2014

Geertz, H. 1983. Keluarga Jawa. Jakarta: Grafiti Pers.

Hamalik, O. 2001. Proses Belajar Mengajar. Jakarta: Bumi Aksara.

Hamalik, O. 2004. Proses Belajar Mengajar. Jakarta: Bumi Aksara.

Hamalik, O. 2008. Psikologi Belajar dan Mengajar. Bandung: Sinar Baru Agresindo.

Hamdani, Nurdin, I., Dewi, R. R., Subarkah, A., \& Rinawati. 2004. Good Govermance dalam Perspektif Budaya Melayu. Pekanbaru: UNRI Press.

Idrus, M. 2012. Pendidikan Karakter Pada Kebudayaan Jawa. Yogyakarta: Universitas Islam Indonesia.

Ihromi. 1999. Pokok-pokok Antropologi Budaya. Jakarta: Yayasan Obor Indonesia.

Majid, A. 2013. Strategi Pembelajaran. Bandung: Remaja Rosdakarya

May, E. 2006. "Potret 3 Desa Transmigrasi Jawa”. Artikel Penelitian Dosen Muda Fakultas Sastra Universitas Andalas, hlm. 1-44.

Mulder, N. 1999. Agama, Hidup Sehari-bari dan Perubahan Budaya. Jakarta: Gramedia Pustaka Utama. 
Naim, M. 1984. Merantau: Minangkabau voluntary migration. Yogyakarta: UGM Press.

Nirwana, H. 2003. Hubungan Tingkat Aspirasi dan Persepsi tentang Belajar dengan Hasil Belajar Matematika Siswa Sekolah Menengah Umum yang Berlatar Belakang Budaya Minangkabau dan Batak.Disertasitidak diterbitkan. Malang: Program Studi Psikologi Pendidikan Pascasarjana UM.

Noordhoom, R. 2010. Organisational Culture and Work Motivation. Bachelor Thesis Organisation and Strategy. Premaster Strategic Menagement.

Ormrod, J. E. 2008. Psikologi Pendidikan: Membantu siswa tumbub dan berkembang. Terjemahan oleh Amitya Kumara.Jakarta: Erlangga.

Purwanto, N. 2010. Psikologi Pendidikan. Bandung: Remaja Rosdakarya.

Poerwadarmita, W. J. S. 1989. Kamus Bahasa Indonesia. Jakarta: Balai Pustaka.

Roqib, M. 2007. Harmoni dalam Budaya Jawa. Yogyakarta: Pustaka Offset.

Samovar, L. A., Porter, R. E., \& McDaniel, E. R. 2010. Komunikasi Lintas Budaya. Terjemahan oleh Indri M. Sidabalok. Jakarta: Salemba Humanika.

Santrock, W. J. 2010. Life Span Development. Terjemahan oleh Triwibowo. Jakarta: Kencana Prenada Media Group.

Sardiman, A. M. 2011. Interaksi dan Motivasi Belajar Mengajar. Jakarta: Raja Grafindo Persada.

Sardiman, A. M. 2012. Interaksi dan Motivasi Belajar Mengajar. Jakarta: RajaGrafindo Persada.

Sardiman, A. M. 2007. Interaksi dan Motivasi Belajar Mengajar. Jakarta: Rajawali.

Sedyawati, E. 2012. Budaya Indonesia: Kajian arkeologi, seni, dan sejarah. Jakarta: Raja Grafindo Persada.

Silalahi, K., \& Meinarno, E. A. 2010. Keluarga Indonesia: Aspek dan dinamika zaman. Jakarta: Rajawali.

Suwardi. 2007. Kebudayaan Melayu. Pekanbaru: Kampus Akademik Pariwisata Engku Puteri Hamida.

Syukur, A. 2012. Studi Budaya di Indonesia. Bandung: Pustaka Setia.

Thamrin, H.2006. Etnografi Melayu Tradisi dan Modernisasi. Lembaga Penelitian dan Pengembangan UIN SUSKA Riau Pekanbaru. 
Undang-undang Sisdiknas (Sistem Pendidikan Nasional) Nomor. 20 Tahun 2003. 2013. Bandung: Diperbanyak oleh Fokus Media. 